\title{
Chronic child poverty and health outcomes in South Africa using a multidimensional poverty measure
}

\author{
MARISA VON FINTEL \\ RONELLE BURGER
}

Stellenbosch Economic Working Papers: WP19/2020

www.ekon.sun.ac.za/wpapers/2020/wp192020

October 2020

KEYWORDS: Poverty measurement, poverty dynamics, health inequality, children, South Africa

JEL: I14, I31, I32

\author{
ReSEP (Research on Socio-Economic Policy) \\ https://resep.sun.ac.za \\ DEPARTMENT OF ECONOMICS \\ UNIVERSITY OF STELLENBOSCH \\ SOUTH AFRICA
}

A WORKING PAPER OF THE DEPARTMENT OF ECONOMICS AND THE BUREAU FOR ECONOMIC RESEARCH AT THE UNIVERSITY OF STELLENBOSCH 


\title{
Chronic child poverty and health outcomes in South Africa using a multidimensional poverty measure
}

\author{
Marisa von Fintel ${ }^{*}$ and Ronelle Burger
}

\begin{abstract}
In this paper, we examine the differences in health outcomes between children residing in poor and non-poor households. In order to identify household poverty, we make use of the framework of multidimensional poverty as introduced by Alkire and Foster (2011). In our sample, we follow all children (defined as individuals aged 18 years or younger) over the period 2012- 2017, using the last three waves of the National Income Dynamics Study (NIDS). We find great disparities in health and well-being among children depending on the classification of the household as being poor or non-poor. In addition, children residing in households which are chronically poor (i.e. are observed to remain in poverty over time) have worse health outcomes than children residing in households which move in and out of poverty, pointing towards the negative effects of poverty traps. Finally, we rely on the previous work conducted by Wagstaff et al (2004) to explore some of the causes of child health inequalities in South Africa, including maternal education, water and sanitation and social norms (which includes the prevalence of female-headed households and the decision-making power of women in the household).
\end{abstract}

Keywords: Poverty measurement, poverty dynamics, health inequality, children, South Africa

JEL codes: $114,131,132$

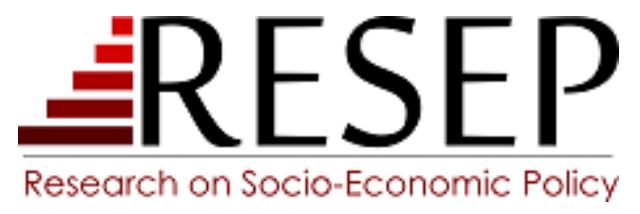

Acknowledgements:

The authors gratefully acknowledge funding for this project by the South African Department of Science and Innovation-National Research Foundation (DSI-NRF) Centre of Excellence in Human Development.

"Research on Socio-Economic Policy (ReSEP), CGW Schumann Building, Department of Economics, Stellenbosch University 


\section{Introduction}

The causes of South Africa's dysfunctional public health system and the corresponding inequalities in health outcomes between the poor and non-poor have been investigated in detail. These causes include, inter alia, historical policies under the Apartheid regime, which explicitly discriminated against individuals based on their race. However, the list also includes other social remnants from this time period, including the migrant labour system, extreme income inequality and leadership and management failures in the public health system (Coovadia, Jewkes, Barron, Sanders, \& McIntyre, 2009). Concentration indices using South African data consistently illustrate the extent of socio-economic inequalities in health outcomes, with the poor being much more likely to suffer from illnesses and disabilities (Ataguba, Akazili, \& McIntyre, 2011).

In this study, we examine the health outcomes of children residing in poor and non-poor households in order to come to a better understanding of the vast differences in well-being between these two groups of children. In addition, we consider the pathways and causes through which these differences have come about.

In order to identify a household as being poor, we make use of a multidimensional poverty measure. Although money-metric measures of child poverty ${ }^{1}$ are sufficiently informative to provide an indication of the broad poverty dynamics of children over time, these measures are limited in that they do not take into consideration the actual well-being of children within the household. In the words of Alkire and Roche $(2011$, p. 3), these measures do not always provide the necessary tools to establish whether "... children ... enjoy a childhood free from fear and want". ${ }^{2}$

One way in which to supplement the usual money-metric measures of poverty is to make use of a multidimensional poverty index, which is comprised of a broader range of well-being indicators (or dimensions) so as to provide a more complete indication of whether a child is deprived or not. In this paper, we will implement the framework of Alkire and Foster (2011), in order to integrate these various dimensions into a single composite index. Alkire and Foster base their approach on Sen's work (1999, inter alia), which has criticised the money-metric approach as being one-dimensional and too simplistic. Making use of a multidimensional approach allows for the consideration of more dimensions of wellbeing which places well-being in the space of capabilities (Alkire \& Roche, 2011). The advantage of using this Multidimensional Poverty Index (MPI) is not only the fact that it includes a wider measure of actual well-being than only income or expenditure, but also the fact that it takes into account the intensity of the poverty, taking the measurement of poverty beyond the headcount.

In the South African context, there have been a few studies that have focussed on measuring poverty in this multidimensional way. Using their MPI, Alkire and Santos (2010) make use of the World Health Survey of 2003 to estimate MPI poverty for South Africa. Finn, Leibbrandt and Woolard (2013) estimate a MPI for South Africa using data from the 1993 Project for Statistics on Living Standards for Development (PSLSD) and wave 2 of the National Income Dynamics Study (NIDS), collected in 2010. Most recently, Statistics South Africa (2014) has adjusted the global MPI for the South African context and implemented this South African MPI approach using census data.

\footnotetext{
${ }^{1}$ I.e. all measures based on income and expenditure.

${ }^{2}$ Alkire and Roche (2011) emphasise the importance of a multidimensional approach to measuring poverty, especially when measuring child poverty. Taking a multidimensional approach to measuring poverty provides policy makers with more information on the depth of the poverty as well as the indicators that children are most deprived in and accordingly warrant the most attention.
} 
Although the MPI approach has been used to estimate overall poverty in South Africa, it has not often been utilised to measure poverty for children per se. ${ }^{3}$ Using a multidimensional approach to estimate child poverty makes much sense, as the method allows for more insight into the contributing factors to the poverty status of the household. This is important for children specifically, who have been shown to be a vulnerable group within the South African context, both in terms of their vulnerability to poverty as well as their exposure to chronic poverty (i.e. persistent poverty over time) (von Fintel, Zoch, \& van der Berg, 2017; Omotoso, Adesina, \& Gbadegesin, 2020). ${ }^{4}$

Internationally, the development of multidimensional poverty measures specifically tailored to measure the needs and wants of children has become quite prevalent. A multidimensional Child Poverty Index has been developed for Bhutan, which allows for various indicators that are specifically aimed at measuring the well-being of children at various stages of development. These include educational needs at various levels of development, as well as an indicator labelled "Childhood Conditions", which aims at capturing the most urgent needs of children aged 0-4 (malnutrition), aged 5-11 (child labour) and girls (who are specifically vulnerable) aged 15-17 years (child brides, and exposure and attitudes to domestic violence) (Alkire, Dorji, Gyeltshen, \& Minten, 2016). Child-centred multidimensional poverty measures have also been applied to children living in various circumstances, including Afghanistan (Trani, Biggeri, \& Vincenzo, 2013), Darfur (Trani \& Cannings, 2013), Columbia (Garcia \& Ritterbusch, 2015) and Australia (Callander, Schofield, \& Shrestha, 2012).

In the South African context, Omotoso \& Koch (2018) developed a child-specific multidimensional poverty measure for South Africa, while Frame, de Lannoy, \& Leibbrandt (2016) developed a multidimensional youth indicator of poverty for individuals aged between 15 and 24 years.

In the analysis below, we do not develop a child-specific measure of poverty, but rather make use of the South African MPI developed by Statistics South Africa (2014), based on Alkire and Foster (2011), to estimate multidimensional child poverty in South Africa. In other words, we identify children as being poor if they were residing in a poor household. ${ }^{5}$

We make use of the National Income Dynamics Survey (NIDS), in order to follow the same children from 2012-2017 (the last three waves of the survey). We then use the classification of children as being multidimensionally poor or not poor to identify inequalities in the health outcomes of children in South Africa. In the final analysis, we consider the causes of these health outcomes, as identified by Wagstaff et al (2004).

\section{Data}

The National Income Dynamics Study (NIDS) is the first nationally representative panel study of its kind in South Africa. It was conducted by the South African Labour and Development Research Unit (SALDRU).

\footnotetext{
${ }^{3}$ The MPI has been used by the South African Human Rights Commission and UNICEF (2014) to calculate child poverty over the period 2008-2012, and has also been used to develop a youth (15-24 years) indicator of poverty (Frame, de Lannoy, \& Leibbrandt, 2016).

${ }^{4}$ In a recent study, Omotoso, Adesina and Gbadegesin (2020) find that there are more children who are vulnerable to multidimensional poverty than children living in chronic poverty.

${ }^{5}$ The main reason for this is that the NIDS data does not lend itself to the development of a child-centered multidimensional poverty index.
} 
The first wave was conducted in 2008, with four subsequent waves of data collected in 2010/2011, 2012, 2014/2015, and 2017. The aim of the NIDS survey was to capture dynamics in income and expenditure over time. It, however, includes a wide variety of questions relating to the health and well-being of household members, which makes it an appropriate data set to use in order to answer questions around child health inequality in South Africa.

For this paper, we consider only the last three waves of the NIDS panel, namely wave 3 (enumerated in 2012), wave 4 (enumerated in 2014/2015), and wave 5 (enumerated in 2017). This is largely motivated by the fact that our sample consists of children who were 18 years old or younger in 2017, and for whom we have completed interviews for all three of these waves. Following this cohort over all five waves would have resulted in too wide an age range and too many missing variables. We therefore restrict our analysis to the most recent three waves.

Table 1 (Appendix A) reports the number of observations in the sample, broken down by wave and age category. From the table it is clear how children age over the period. Because we do not include childspecific dimensions in our measure of the MPI, but rather focus on the household's poverty status, the differences in the age categories over time should not affect the results too much.

\section{Measuring Multidimensional Child Poverty in South Africa}

Before reporting the results from applying the MPI framework, it is necessary to briefly discuss the process behind defining an index. Alkire and Roche (2011) provide a detailed discussion of the steps involved in the compilation of an MPI for the purpose of measuring child poverty using the Alkire Foster method.

In the first place, it is necessary to identify the unit of analysis. In this paper, the unit of analysis will be the individual child, ${ }^{6}$ although many of the indicators will be measured at the household level.

Second, it is important to choose the most appropriate dimensions as well as the indicators that will comprise the MPI. We set out the dimensions and indicators we have chosen as well as a detailed description of each dimension below in Table 2. The choice of dimensions and indicators have been primarily influenced by the approach adopted by Statistics South Africa (2014) in their development of the South African MPI. The main difference between these dimensions and the dimensions included in the global version of the MIP is that Statistics South Africa included economic activity as a separate dimension in the index. This dimension provides information on the extent of households' access to the labour market. In South Africa, having someone in the household who is employed is a sign of having a link to the formal labour market, which is a very important factor in determining whether the household is poor or not. Access to the labour market has been shown to be the single biggest determinant of whether a household will move into or out of poverty over time, apart from race (Finn \& Leibbrandt, 2016). This should be interpreted in the context of South Africa's very high unemployment rate, which was estimated to be around 29\% in the second quarter of 2019 (Statistics South Africa, 2019).

Third, the deprivation cut-off for each indicator needs to be established. Again, we follow the approach by Statistics South Africa (2014). The cut-offs we apply have also been set out in the detailed description of each indicator in Table 2.

\footnotetext{
${ }^{6}$ We define children as being all individuals who were 18 years or younger in 2017.
} 
Fourth, after having chosen the indicators and their individual cut-offs, it is necessary to decide on the weights for each of the indicators. We have followed the approach of weighting each dimension equally, and then dividing the weight of the dimension by the number of indicators per dimension. This allows us to remain agnostic about the relative important of each dimension, as it is clear that a non-poor child should ideally not be deprived in any of these dimensions. The weights for each of the indicators are set out in Table 4 below.

Fifth, we choose a second cut-off of $1 / 3$ for our poverty line. In other words, we identify a child as poor if they reside in a household where they are deprived in a third or more of the weighted indicators. This cut-off was selected as it is in line with Alkire and Santos (2010) and Finn, Leibbrandt and Woolard (2013).

Table 2: The Multidimensional Poverty Index of South Africa (SAMPI)

\begin{tabular}{|c|c|c|}
\hline Dimension & Indicator & Deprivation cut-off \\
\hline Health & Child mortality & $\begin{array}{l}\text { If any child under the age of } 5 \text { has died in the past } \\
12 \text { months }\end{array}$ \\
\hline \multirow{2}{*}{ Education } & Years of schooling & $\begin{array}{l}\text { If no household member aged } 15 \text { or older has } \\
\text { completed } 5 \text { years of schooling }\end{array}$ \\
\hline & School attendance & $\begin{array}{l}\text { If any school-aged child (aged } 7 \text { to } 15 \text { ) is out of } \\
\text { school }\end{array}$ \\
\hline \multirow{7}{*}{ Standard of living } & Fuel for lighting & $\begin{array}{l}\text { If household is using } \\
\text { paraffin/candles/nothing/other* }\end{array}$ \\
\hline & Fuel for heating & $\begin{array}{l}\text { If household is using } \\
\text { paraffin/wood/coal/dung/other*/none }\end{array}$ \\
\hline & Fuel for cooking & $\begin{array}{l}\text { If household is using } \\
\text { paraffin/wood/coal/dung/other*/none }\end{array}$ \\
\hline & Water access & If no piped water in dwelling or on stand \\
\hline & Sanitation type & If not a flush toilet \\
\hline & Dwelling type & $\begin{array}{l}\text { If an informal shack/traditional } \\
\text { dwelling/caravan/tent/other* }\end{array}$ \\
\hline & Asset ownership & $\begin{array}{l}\text { If household does not own more than one of } \\
\text { radio, television, telephone or refrigerator and } \\
\text { does not own a car }\end{array}$ \\
\hline Economi & Unemployment & $\begin{array}{l}\text { If all adults (aged } 15 \text { to } 64 \text { ) in the household are } \\
\text { unemployed }\end{array}$ \\
\hline
\end{tabular}

Source: Statistics South Africa (2014: 6).

Notes: * The category "other" refers to a different type of fuel, which has not been listed in the table (and excludes the use of electricity or gas).

Sixth, we calculate the headcount ratio $(H)$, Average Intensity $(A)$ and the MPI $\left(H^{*} A\right)$. The headcount ratio refers to the proportion of children who are deprived in $1 / 3$ or more of the weighted indicators. The average intensity is the mean deprivation level for children who have been identified as being MPI poor. We calculate the MPI as the product between these two measures.

Seventh, we calculate the contribution by dimension, using the following formula:

$$
\text { Contribution }_{i}=100 *\left(\frac{w_{i} * C H_{i}}{M P I}\right)
$$


Where the contribution of each indicator $i$ is a function of the weight of the indicator $\left(w_{i}\right)$; the censored headcount of indicator $i\left(\mathrm{CH}_{i}\right.$, which is the number of children who are both MPI poor and deprived in terms of indicator $i$ divided by the total sample); and the MPI. This allows us to identify the indicators which require policy intervention most urgently.

Table 3 reports $\mathrm{H}, \mathrm{A}$ and the MPI for each year. It is clear that both the headcount and intensity of poverty have decreased for children in the sample over time.

Table 3: Headcount, Intensity and Adjusted Headcount

\begin{tabular}{|l|l|l|l|}
\hline \multicolumn{1}{|c|}{ Year } & Headcount ratio (H) & Intensity (A) & Adjusted Headcount ratio ( MO) \\
\hline 2012 & $16.57 \%$ & $42.20 \%$ & 0.07 \\
$2014 / 2015$ & $14.06 \%$ & $41.46 \%$ & 0.06 \\
2017 & $13.04 \%$ & $40.46 \%$ & 0.05 \\
\hline
\end{tabular}

Source: NIDS 2012, 2014/2015, and 2017.

Notes: Poverty rates were calculated for the sample of children aged 18 or younger in 2017 and who remained in the sample throughout the three waves (data have been weighted using panel weights). Table indicates the proportion of children classified as being MPI poor using the poverty cut-off of $33.33 \%$.

In order to get a better idea of the distribution of poverty over the various dimensions, we also report a breakdown of the uncensored headcount ratios per indicator and dimension in Table 4 (Appendix A). The uncensored headcount ratio per indicator essentially provides information on the proportion of children who were observed to be deprived in the indicator (i.e. whose household was below the threshold for the individual indicator). For most indicators, this breakdown indicates the great strides which have been taken to reduce deprivation among children over time. For most indicators, the headcount ratio has decreased from 2012 to 2017. However, for some indicators, the proportion of children deprived in that indicator has not changed over time, pointing out the areas in which there are still some room for improvement. These include access to safe and clean water and sanitation, as well as access to the labour market.

A similar breakdown of the results is presented in Table 5 (Appendix A), which summarises the percentage of children deprived in each indicator, broken down by whether they were residing in multidimensionally poor or non-poor households (i.e. the conditional headcount ratios by indicator). Again, the three indicators where there has not been a decrease in the headcount ratio are sanitation, water, and unemployment.

It is therefore not surprising that the unemployment indicator was by far the greatest contributor to the $\mathrm{MPI}$, and that its contribution increased over the three waves (see Table 6 below).

\section{Health Inequalities and Multidimensional Poverty}

In this section, we examine the health outcomes of children, distinguishing between children who were residing in multidimensionally poor households and those who were not. We also consider the severity of the multidimensional poverty over time by distinguishing between children who were in multidimensionally poor households in all three waves, versus those who moved into and out of poverty over the time period.

Chronic poverty, i.e. experiencing poverty consistently over time, can be seen as an indicator that the household is stuck in a poverty trap, without the necessary assets to move out of poverty over time (von Fintel, Zoch, \& van der Berg, 2017). Children who remained in poor households for all three waves are 
therefore likely to experience worse health outcomes compared to children who were residing in a poor household for only one or two of the three waves. ${ }^{7}$

Table 6: Contribution of weighted indicators of SAMPI

\begin{tabular}{|lccc|}
\hline Contribution & $\mathbf{2 0 1 2}$ & $\mathbf{2 0 1 4 / 1 5}$ & $\mathbf{2 0 1 7}$ \\
\hline Child mortality & $1.51 \%$ & $0.84 \%$ & $0.25 \%$ \\
Years of schooling & $3.00 \%$ & $2.93 \%$ & $3.20 \%$ \\
School attendance & $0.50 \%$ & $0.42 \%$ & $0.60 \%$ \\
Fuel for lighting & $3.39 \%$ & $3.01 \%$ & $1.99 \%$ \\
Fuel for heating & $7.18 \%$ & $7.10 \%$ & $7.01 \%$ \\
Fuel for cooking & $5.92 \%$ & $5.52 \%$ & $4.61 \%$ \\
Water access & $6.48 \%$ & $6.51 \%$ & $7.04 \%$ \\
Sanitation type & $8.16 \%$ & $8.26 \%$ & $8.46 \%$ \\
Dwelling type & $3.59 \%$ & $4.39 \%$ & $3.73 \%$ \\
Asset ownership & $1.78 \%$ & $1.80 \%$ & $1.81 \%$ \\
Unemployment & $58.61 \%$ & $59.23 \%$ & $61.29 \%$ \\
\hline
\end{tabular}

Source: NIDS 2012, 2014/2015, and 2017.

Notes: Poverty rates were calculated for the sample of children aged 18 or younger in 2017 and who remained in the sample throughout the three waves (data have been weighted using panel weights). Table indicates the proportion of children classified as being MPI poor using the poverty cut-off of $33.33 \%$.

We consider five health outcomes. In order to capture long-run nutrition, we consider the weight-forheight z-score as well as whether the child is stunted for children in the sample aged between birth and 5 years. To capture short-run nutrition, we consider the height-for-age $z$ score as well as wasting for children aged between birth and 18 years. Finally, we also consider the self-reported health score, as reported by the caregiver of the child, as a score between 1 (worst) to 5 (best).

Table 7 reports the means and standard deviations for each of these health outcomes of the sub-sample of children who resided in multidimensionally poor and non-poor households, for the pooled sample over all three waves. It also provides an indication of whether the differences between these two groups are statistically significantly different, based on a t-test of the differences of the means.

A similar summary is reported in Table 8, where we compare the differences in means between three groups of children: those who were never in poverty over the three waves of the study, those who moved into and out of poverty so that they were observed to reside in a poor household for either 1 or 2 of the three waves of the study, and those who were chronically poor (i.e. in a multidimensional poor household for all three waves).

Both tables indicate that children who resided in multidimensionally poor households were more likely to suffer from long-run nutritional deprivation, having both lower height-for-age z-scores and a higher probability to be stunted. This is also true for children who have been in chronic poverty over the period

\footnotetext{
${ }^{7}$ Although chronic multidimensional poverty can be measured using the duration approach, i.e. where a separate cut-off is applied to ascertain whether a child was chronically multidimensionally poor or not, here we rely on the simpler method of identifying a child as chronically poor if he or she were observed to reside in a poor household in all three time periods.
} 
as well, compared to children who have moved out of and into poverty over the three waves, providing evidence of the impact of poverty traps.

On the contrary, multidimensionally poor children have a higher weight-for height z-score, and children who were in chronic multidimensional poverty over the period have a higher weight-for-height z-score compared to children who moved into and out of poverty over the period. This seemingly contradictory result is however in line with existing literature on the topic (Symington, Gericke, Nel, \& Labadarios, 2016), which identify poor children in South Africa as being both overweight and stunted, providing evidence of the "double burden of malnutrition" prevalent in many low and middle income countries around the world (Nyati, Pettifor, \& Norris, 2019).

Table 7: Child health outcomes between poor and non-poor (2012-2017)

\begin{tabular}{|c|c|c|c|}
\hline Health outcome & $\begin{array}{l}\text { Children residing in } \\
\text { multidimensionally poor } \\
\text { household }\end{array}$ & $\begin{array}{l}\text { Child residing in non- } \\
\text { multidimensionally poor } \\
\text { household }\end{array}$ & $\begin{array}{l}\text { Differences statistically } \\
\text { significant? } \\
\text { (t-statistic for differences } \\
\text { in means) }\end{array}$ \\
\hline & Mean (standard deviation) & Mean (standard deviation) & $\begin{array}{l}* * *_{\mathrm{p}}<0.01 \\
* * \mathrm{p}<0.05 \\
* \mathrm{p}<0.1\end{array}$ \\
\hline Height-for-age z-score & $-0.962(1.253)$ & $-0.821(1.210)$ & $* * *$ \\
\hline $\begin{array}{l}\text { Proportion } \quad \text { stunted } \\
\text { (only children } 0-5 \text { years) }\end{array}$ & $0.176(0.381)$ & $0.140(0.347)$ & $* * *$ \\
\hline $\begin{array}{l}\text { Weight-for-height z- } \\
\text { score (only children } \\
\text { aged 0-5 years) }\end{array}$ & $0.611(1.477)$ & $0.507(1.456)$ & $*$ \\
\hline Proportion wasted & $0.051(0.221)$ & $0.045(0.207)$ & \\
\hline $\begin{array}{l}\text { Self-reported health } \\
\text { (increasing scale from } 1 \\
\text { to 5) }\end{array}$ & $4.24(0.828)$ & $4.277(0.824)$ & $* *$ \\
\hline
\end{tabular}

Source: NIDS 2012, 2014/2015, and 2017.

Notes: Sample includes children aged 18 or younger in 2017 and who remained in the sample throughout the three waves (data have been weighted using panel weights). Table identifies child as multidimensionally poor using the poverty cut-off of $33.33 \%$.

Irrespective of this result, wasting is more prevalent among children in multidimensionally poor households, and even more likely to have occurred among children in chronically multidimensionally poor households.

The self-reported health score for children in multidimensionally poor households is on average lower than for children in non-poor households. Similarly, children in chronically multidimensionally poor households have lower self-reported health scores than children who moved into and out of poverty over the three waves. However, these differences are small and not statistically significantly different. This result is almost certainly driven, at least in part, by differences in perception of what good health entails within the sample. Research using vignettes as reference point has illustrated how heterogeneous reporting can lead to an underestimation of the inequalities of health outcomes between the poor and non-poor (Rossouw, Bago d'Uva, \& van Doorslaer, 2018) 
Table 8: Child health outcomes between chronically poor and chronically non-poor (2012-2017)

\begin{tabular}{|c|c|c|c|}
\hline Health outcome & $\begin{array}{l}\text { Multidimensionally non- } \\
\text { poor }\end{array}$ & $\begin{array}{l}\text { Move into and out of poverty } \\
\text { over } 3 \text { waves (child residing in } \\
\text { multidimensionally poor } \\
\text { household in } 1 \text { or } 2 \text { waves) }\end{array}$ & $\begin{array}{l}\text { Chronically } \\
\text { multidimensionally poor } \\
\text { (children residing in } \\
\text { multidimensionally poor } \\
\text { household in all three } \\
\text { waves) }\end{array}$ \\
\hline & $\begin{array}{ll}\text { Mean } & \text { (standard } \\
\text { deviation) }\end{array}$ & Mean (standard deviation) & Mean (standard deviation) \\
\hline Height-for-age z-score & $-0.809(1.206)$ & $-0.902(1.233)$ & $-1.018(1.280)$ \\
\hline $\begin{array}{l}\text { Proportion stunted (only } \\
\text { children } 0-5 \text { years) }\end{array}$ & $0.139(0.346)$ & $0.155(0.362)$ & $0.196(0.397)$ \\
\hline $\begin{array}{l}\text { Weight-for-height } \\
\text { score (only children aged } \\
0-5 \text { years) }\end{array}$ & 0.504 (1.429) & $0.553(1.528)$ & $0.679(1.471)$ \\
\hline Proportion wasted & $0.041(0.198)$ & $0.057(0.232)$ & $0.049(0.217)$ \\
\hline $\begin{array}{l}\text { Self-reported health } \\
\text { (increasing scale from } 1 \\
\text { to } 5 \text { ) }\end{array}$ & $4.275(0.829)$ & $4.264(0.816)$ & $4.260(0.828)$ \\
\hline
\end{tabular}

Source: NIDS 2012, 2014/2015, and 2017.

Notes: Sample includes children aged 18 or younger in 2017 and who remained in the sample throughout the three waves (data have been weighted using panel weights). Table identifies child as multidimensionally poor using the poverty cut-off of $33.33 \%$.

\section{The Causes of Child Health Inequalities}

In the final part of the analysis, we consider the factors highlighted by Wagstaff et al (2004) as determinants of the socio-economic inequalities in child health globally. From their systematic review of the literature on the topic, they identify several "proximate" as well as "underlying" causes of these health inequalities (Mosley \& Chen, 1984). These factors have also in the literature been divided into "biological" and "socio-economic" factors (Richter, et al., 2018).

Proximate or biological causes refer to the factors affecting the health of children directly, and include health care provided to the mother during pregnancy and at childbirth, as well as other measures taken to ensure the well-being of the child after childbirth, such as feeding practices. Underlying or socioeconomic causes include factors such as the mother's education, household income and access to health facilities. These factors only have an effect on children's health through their effect on proximate determinants, as argued by Wagstaff et al (2004).

Because the NIDS data is primarily aimed at capturing household income and poverty over time, the focus of the survey was not to capture health-related data. Therefore, variables capturing proximate causes are less frequently available in the NIDS data.

We include only low birthweight (which has been shown to be correlated with worse growth outcomes for children later in life (Richter, et al., 2018)) in the list of proximate causes, as well as whether the child's caregiver was able to show the child's clinic card, as a proxy for whether the child has been immunised or not. 
As for the underlying causes, Wagstaff et al (2004) identify 4 broad categories which we also use to focus the discussion:

\section{Financial Barriers}

The NIDS data allows us to consider the income and expenditure levels of the household, as these influence various proximate causes, including antenatal care, child immunization (Wagstaff et al, 2004), and health-seeking behaviour in the event of a child being ill (Lassi, Middleton, Bhutta, \& Crowther, 2019). In addition, we also consider whether the household has experienced a negative economic shock during the past 24 months, including theft, fire, or destruction of property, widespread death and/or disease of livestock, major crop failure, the death of a family member and/ breadwinner, or the loss of income by a reduction in social grants. ${ }^{8}$ These negative household events provide more insight into the financial vulnerability of households, apart from the income and expenditure data.

\section{Health Care Provision}

The NIDS data on its own does not allow us to examine the quality of the health care facility available to individuals in the sample. However, the best proxy for such quality is the geographic region in which the individual resides, with individuals in rural areas in South Africa being on average much further away from a health care facility than individuals residing in urban areas (McLaren, Ardington, \& Leibbrandt, 2013). Distance to health care facility has been shown to be a barrier to health care utilitzation (McLaren, Ardington, \& Leibbrandt, 2013).

\section{Maternal Education}

Maternal education has an obvious influence on the health outcomes of children, as has been shown in both international and South African studies on the topic (Ohonba, Ngepah, \& Simo-Kengne, 2019). Proximate causes of health outcomes are usually correlated with mothers' education, and less educated mothers also tend to be poorer, entrenching the inequalities in children's health outcomes (Wagstaff et al, 2004). We have also included a variable capturing whether the child's mother is deceased, as maternal orphanhood increases the vulnerability of the child.

\section{Water, Sanitation and the Home Environment}

Since our index is a multidimensional index, we have already included many of the variables in this category in the identification of poor and non-poor households, including access to clean drinking water and sanitation. However, from the prior analysis, it is clear that these indicators play an important role in the determination of multidimensional poverty for children, with water and sanitation contributing between $6 \%-8 \%$ of the poverty index. In addition, approximately $75 \%$ and $85 \%$ of children who are residing in multidimensionally poor households are deprived of safe drinking water and sanitation respectively (see Table 6 above).

However, for the purposes of this analysis, we have included various other metrics describing the home environment, including the demographic make-up of the household (proportion of children and elderly residing in the household) as well as whether the household is female headed. These factors are correlated with poverty and vulnerability (von Fintel, Zoch, \& van der Berg, 2017). In addition, there is a gender gap between male and female-headed households in South Africa when using the MPI, i.e.

\footnotetext{
${ }^{8}$ It should be noted that the last two items were only asked in the third wave in 2012, and not in the last two waves.
} 
female-headed households are on average poorer and more vulnerable than male-headed households (Rogan, 2016)

Last, as a proxy for female empowerment in the household, we have included a variable capturing whether females are the main decision-maker for any of the decisions listed in the NIDS questionnaire. These include decisions about household expenses, who may reside in the household or not, where the household should live, and where children in the household go to school. Female empowerment in the household matters for the health of children in at least two ways. First, female bargaining power to control household finances has been shown to be correlated with better maternal care during pregnancy (Beegle, Frankenberg, \& Thomas, 2001). In addition, female access to household finances is associated with better child well-being (Patel, Knijn, \& van Wel, 2015).

Table 9 reports the results distinguishing the differences in means between children who reside in multidimensionally poor households and children who do not, pooling the data for all three waves together. As expected, children who reside in multidimensionally poor households are worse off in all respects compared with children who reside in multidimensionally non-poor households.

Table 10 provides details of the household characteristics according to the chronic multidimensional poverty status of the household. In the second column are children who were not observed to be in a multidimensionally poor household in any of the three waves, in the third column are children who were observed to reside in a multidimensionally poor household for one or two waves out of the three, and in the last column are children who were chronically poor over the period. In other words, these chronically poor children were observed to reside in multidimensionally poor households for all three of the waves.

Table 10 also indicates that children who were chronically poor were more likely to reside in households which exhibit worse characteristics, even compared with children who moved into and out of poverty over the period.

Both of these tables provide some support for the proximate and underlying causes discussed above. It would appear as if children who are multidimensionally poor, and especially children who are chronically multidimensionally poor, experience worse health outcomes as a result of the causes discussed in Wagstaff et al (2004), namely financial barriers, health care provision, maternal education and home environment.

The one exception to this result is the variable capturing female decision-making power within the household as a proxy for women's empowerment. It appears as if women are more likely to be the main decision-makers in their households in poorer (and chronically poor) households. This result seems counter-intuitive, given the findings in the literature discussed above. However, the number of femaleheaded households in this group provides an explanation for this result. In fact, in the sample for femaleheaded households, females are the main decision-makers in at least one area in approximately $64 \%$ of the households, whereas for male-headed households, this figure is only $21 \%$. 
Table 9: Analysis of proximate causes of poor health outcomes: multidimensionally poor and non-poor children

\begin{tabular}{|c|c|c|c|}
\hline & $\begin{array}{l}\text { Children residing in } \\
\text { multidimensionally poor } \\
\text { household }\end{array}$ & $\begin{array}{l}\text { Child residing in non- } \\
\text { multidimensionally poor } \\
\text { household }\end{array}$ & $\begin{array}{l}\text { Differences } \\
\text { statistically } \\
\text { significant? } \\
\text { (t-statistic for } \\
\text { differences in means) }\end{array}$ \\
\hline & Mean (standard deviation) & Mean (standard deviation) & $\begin{array}{l}* * * \mathrm{p}<0.01 \\
* * \mathrm{p}<0.05 \\
* \mathrm{p}<0.1\end{array}$ \\
\hline $\begin{array}{l}\text { Proportion with low } \\
\text { birthweight (only children } \\
\text { aged 0-14 years) }\end{array}$ & $0.490(0.500)$ & $0.402(0.490)$ & $* * *$ \\
\hline $\begin{array}{l}\text { Caregiver was able to show } \\
\text { child's clinic card }\end{array}$ & $0.658(0.474)$ & $0.711(0.453)$ & $* * *$ \\
\hline Per capita household income & $505.02(531.79)$ & $1390.63(6566.49)$ & $* * *$ \\
\hline $\begin{array}{l}\text { Per capita household } \\
\text { expenditure }\end{array}$ & 405.615 (495.379) & 960.409 (1967.85) & $* * *$ \\
\hline $\begin{array}{l}\text { Proportion of households } \\
\text { which experienced negative } \\
\text { shock in last } 24 \text { months }\end{array}$ & $0.263(0.440)$ & $0.239(0.427)$ & $* * *$ \\
\hline $\begin{array}{l}\text { Household resides in rural } \\
\text { area }\end{array}$ & $0.924(0.266)$ & $0.492(0.500)$ & $* * *$ \\
\hline Mother's education & $8.451(3.676)$ & $9.716(3.203)$ & $* * *$ \\
\hline Mother deceased & $0.071(0.257)$ & $0.063(0.243)$ & $* *$ \\
\hline $\begin{array}{l}\text { Mean age of household } \\
\text { members }\end{array}$ & $22.297(0.441)$ & $22.841(6.403)$ & $* * *$ \\
\hline $\begin{array}{l}\text { Proportion of household } \\
\text { consist of children (younger } \\
\text { than } 18 \text { years old) }\end{array}$ & $0.613(0.142)$ & $0.539(0.147)$ & $* * *$ \\
\hline $\begin{array}{l}\text { Proportion of household } \\
\text { consists of elderly (older } \\
\text { than } 60 \text { years) }\end{array}$ & $0.094(0.127)$ & $0.054(0.098)$ & $* * *$ \\
\hline $\begin{array}{l}\text { Females have decision- } \\
\text { making power in the } \\
\text { household }\end{array}$ & $0.592(0.491)$ & $0.493(0.500)$ & $* * *$ \\
\hline Female-headed household & $0.814(0.390)$ & $0.679(0.467)$ & $* * *$ \\
\hline
\end{tabular}

Source: NIDS 2012, 2014/2015, and 2017.

Notes: Sample includes children aged 18 or younger in 2017 and who remained in the sample throughout the three waves (data have been weighted using panel weights). Table identifies child as multidimensionally poor using the poverty cut-off of $33.33 \%$. 
Table 10: Analysis of proximate causes of poor health outcomes: chronically multidimensionally poor and nonpoor children

\begin{tabular}{|c|c|c|c|}
\hline & $\begin{array}{l}\text { Multidimensionally non- } \\
\text { poor in all three waves }\end{array}$ & $\begin{array}{l}\text { Move into and out of poverty } \\
\text { over } 3 \text { waves (child residing in } \\
\text { multidimensionally poor } \\
\text { household in } 1 \text { or } 2 \text { waves) }\end{array}$ & $\begin{array}{l}\text { Chronically } \\
\text { multidimensionally poor } \\
\text { (children residing in } \\
\text { multidimensionally poor } \\
\text { household in all three } \\
\text { waves) }\end{array}$ \\
\hline & $\begin{array}{ll}\text { Mean } & \text { (standard } \\
\text { deviation) } & \end{array}$ & Mean (standard deviation) & Mean (standard deviation) \\
\hline 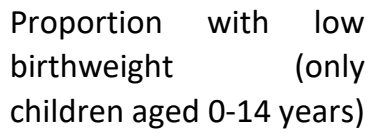 & $0.395(0.489)$ & $0.452(0.498)$ & $0.527(0.499)$ \\
\hline $\begin{array}{l}\text { Caregiver was able to } \\
\text { show child's clinic card }\end{array}$ & $0.711(0.453)$ & $0.658(0.474)$ & $0.593(0.491)$ \\
\hline $\begin{array}{l}\text { Per capita household } \\
\text { income }\end{array}$ & $1534.50(7285.55)$ & $659.68(1071.91)$ & $514.546(359.00)$ \\
\hline $\begin{array}{l}\text { Per capita household } \\
\text { expenditure }\end{array}$ & $1063.31(1816.30)$ & 476.661 (798.595) & $401.834(426.145)$ \\
\hline 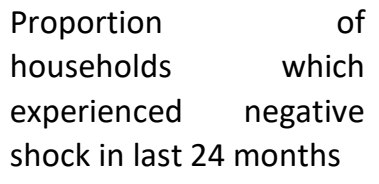 & $0.235(0.424)$ & $0.260(0.439)$ & $0.256(0.437)$ \\
\hline $\begin{array}{l}\text { Household resides in } \\
\text { rural area }\end{array}$ & $0.413(0.492)$ & $0.856(0.351)$ & $0.970(0.170)$ \\
\hline Mother's education & $9.987(2.996)$ & $8.484(3.771)$ & $8.611(3.372)$ \\
\hline Mother deceased & $0.063(0.242)$ & $0.067(0.249)$ & $0.078(0.266)$ \\
\hline $\begin{array}{l}\text { Mean age of household } \\
\text { members }\end{array}$ & $22.940(6.383)$ & $22.323(6.836)$ & $22.530(7.705)$ \\
\hline $\begin{array}{l}\text { Proportion of household } \\
\text { consist of children } \\
\text { (younger than } 18 \text { years } \\
\text { old) }\end{array}$ & $0.531(0.147)$ & $0.586(0.144)$ & $0.628(0.138)$ \\
\hline $\begin{array}{l}\text { Proportion of household } \\
\text { consists of elderly (older } \\
\text { than } 60 \text { years) }\end{array}$ & $0.051(0.096)$ & $0.078(0.114)$ & $0.106(0.138)$ \\
\hline $\begin{array}{l}\text { Females have decision- } \\
\text { making power in the } \\
\text { household }\end{array}$ & $0.483(0.500)$ & $0.600(0.496)$ & $0.611(0.488)$ \\
\hline $\begin{array}{l}\text { Female-headed } \\
\text { household }\end{array}$ & $0.661(0.474)$ & $0.778(0.415)$ & $0.833(0.373)$ \\
\hline
\end{tabular}

Source: NIDS 2012, 2014/2015, and 2017.

Notes: Sample includes children aged 18 or younger in 2017 and who remained in the sample throughout the three waves (data have been weighted using panel weights). Table identifies child as multidimensionally poor using the poverty cut-off of $33.33 \%$. 


\section{Conclusion}

In this paper, we examine inequalities in health outcomes by comparing the health outcomes of children residing in poor and non-poor households in South Africa. We define poverty according to a multidimensional approach, using the framework developed by Alkire and Foster (2011). For this purpose, we follow the same children over a 5-year period, from 2012-2017, using data from NIDS. We also consider differences in household circumstances as evidence of the proximate and underlying causes of these inequalities in health outcomes. We find that children who reside in multidimensionally poor households are much worse off than children who reside in non-multidimensionally poor households. In addition, children who were in chronically poor households (i.e. multidimensionally poor in all three waves) experiencing even worse health outcomes than those children who were only observed to reside in poor households for one or two of the three waves. The causes of these disparities include antenatal care for mothers and babies (the results of which can be measured by the birthweight of the child), financial and access barriers to quality health care, maternal education and home environment, including access to clean drinking water and sanitation, and access to the labour market. 


\section{Reference list}

Alkire, S., \& Roche, J. (2011). Beyond Headcount: Measures that Reflect the Breadth and Components of Child Poverty. Oxford Poverty and Human Development Initiative(OPHI) Working Paper.

Alkire, S., \& Foster, J. (2011). Counting and Mutidimensional Poverty Measurement. Journa of Public Economics, 95(7-8).

Alkire, S., \& Santos, M. E. (2010). South Africa Country Briefing. Oxford Poverty and Human Development Initiative (OPHI) Multidimensional Poverty Index Country Briefing Series. Retrieved from www.ophi.org.uk/policy/multidimensional-poverty-index/mpi-country-briefings/

Alkire, S., Dorji, L., Gyeltshen, S., \& Minten, T. (2016). Child Poverty in Bhutan: Insights from Multidimensional Child Poverty Index (C-MPI_ and Qualitative Interviews with Poor Children. Timphu: Bhutan National Statistics Bureau.

Ataguba, J. E., Akazili, J., \& McIntyre, D. (2011). Socioeconomic-related health inequality in South Africa: evidence from General Household Surveys. International Journal for Equity in Health, 10(48), 110.

Beegle, K., Frankenberg, E., \& Thomas, D. (2001). Bargaining power within couples and use of prenatal and delivery care in Indonesia. Studies in Family Planning, (32), 130-146.

Callander, E. J., Schofield, D. J., \& Shrestha, R. N. (2012). Capacity for Freedom - A New Way of Measuring Poverty Amongst Australian Children. Child Indicators Research, 5, 179-198.

Coovadia, H., Jewkes, R., Barron, P., Sanders, D., \& McIntyre, D. (2009). The health and health system of South Africa: historical roots of current public health challenges. The Lancet, 374(9692), 817834.

Finn, A., \& Leibbrandt, M. (2016). The Dynamics of Poverty in the First Four Waves of NIDS. Southern Africa Labour and Development Research Unit (Saldru), 174.

Finn, A., Leibbrandt, M., \& Woolard, I. (2013). What happened to multidimensional poverty in South Africa between 1993 and 2010? Southern Africa Labour and Development Unit (SALDRU) Working Paper Number 99.

Frame, E., de Lannoy, A., \& Leibbrandt, M. (2016). Measuring multidimensional poverty among youth in South Africa at the subnational level. Saldru Working Paper number 169.

Garcia, S., \& Ritterbusch, A. (2015). Child Poverty in Columbia: Construction of a Multidimensional Measure Using a Mixed-Method Approach. Child Indicators Research, 8, 801-823.

Gustafsson, M. (2005). The relationships between schooling inputs and outputs in South Africa: Methodologies and policy recommendations based on the 2000 SACMEQ dataset. Retrieved from http://www.sacmeq.org.org/links.htm

Lassi, Z. S., Middleton, P., Bhutta, Z. A., \& Crowther, C. (2019). Health care seeking for maternal and newborn illnesses in low- and middle-income countries: a systematic review of observational and qualitative studies. F1000 Research, 1-14.

Leibbrandt, M., Finn, A., \& Woolard, I. (2011). Describing and decomposing postapartheid income inequality in South Africa. Development Southern Africa, 19(1), 19-34.

McLaren, Z., Ardington, C., \& Leibbrandt, M. (2013). Distance as a barrier to health care access in South Africa. Southern Africa Labour and Development Research Unit (SALDRU) Working Paper number 97. 
Mosley, W. H., \& Chen, L. C. (1984). An analytical framework for the study of child survival in developing countries. Population and Development Review, 10, 25-45.

Nyati, L. H., Pettifor, J. M., \& Norris, S. A. (2019). The prevalence of malnutrition and growth percentiles for urban South African children. BMC Public Health, 19(492).

Ohonba, A., Ngepah, N., \& Simo-Kengne, B. (2019). Maternal education and child health outcomes in South Africa: A panel data analysis. Development Southern Africa, 36(1), 33-49.

Patel, L., Knijn, T., \& van Wel, F. (2015). Child Support Grants in South Africa: A Pathway to Women's Empowerment and Child Well-being? . Journal of Social Policy, 44(2), 377-397.

Richter, L. M., Orkin, F. M., Roman, G. D., Dahly, D. L., Horta, B. L., Bhargava, S. K., . . Stein, A. (2018). Comparative Models of Biological and Social Pathways to Predict Child Growth through Age 2 Years from Birth Cohorts in Brazil, India, the Philippines, and South Africa. Journal of Nutrition, 148(8), 1364-1371.

Rogan, M. (2016). Gender and Multidimensional Poverty in South Africa: Applying the Global Multidimensional Poverty Index (MPI). Social Indicators Research, 126(3), 987-1006.

Rossouw, L., Bago d'Uva, T., \& van Doorslaer, E. (2018). Poor Health Reporting? Using Anchoring Vignettes to Uncover Health Disparities by Wealth and Race. Demography, 55, 1935-1956.

Sen, A. (1999). Development as Freedom. Oxford: Oxford University Press.

South African Human Rights Commission and UNICEF. (2014). Poverty Traps and Social Exclusion Among Children in South Africa. Pretoria: SAHRC.

Statistics South Africa. (2014). The South African MPI: Creating a Multidimensional Poverty Index using Census Data. Report Number 03-10-08.

Statistics South Africa. (2019, July 31). Statistics South Africa. Retrieved from http://www.statssa.gov.za/?p=12376

Symington, E., Gericke, G., Nel, J., \& Labadarios, D. (2016). The relationship between stunting and overweight among children from South Africa: Secondary analysis of the National Food Consumption Survey - Fortification Baseline I. South African Medical Journal, 106(1), 65-69.

Trani, J.-F., \& Cannings, T. I. (2013). Child Poverty in an Emergency and Conflict Context: A Multidimensional Profile and an Identification of the Poorest Children in Western Darfur. World Development, 48, 48-70.

Trani, J.-F., Biggeri, M., \& Vincenzo, M. (2013). The MUltidimensionality of Child Poverty: Evidence from Afghanistan. Social Indicators Research, 112, 391-416.

Van der Berg, S., Burger, C., Burger, R., de Vos, M., du Rand, G., Gustafsson, M. M., . . . von Fintel, D. (2011). Low Quality Schooling as a Poverty Trap. University of Stellenbosh, Department of Economics.

von Fintel, M., Zoch, A., \& van der Berg, S. (2017). The Dynamics of Child Poverty in South Africa Between 2008 and 2012. Child Indicators Research, 10 (4), 945-969.

Wagstaff, A., Bustreo, F., Bryce, J., Claeson, M., \& Group, W.-B. C. (2004). Child Health: Reaching the Poor. American Journal of Public Health, 94(5), 726-736. 


\section{Appendix A}

Table 1: Describing the sample: Absolute number of children (percentage per wave in parentheses)

\begin{tabular}{|l|lll|}
\hline & $\begin{array}{l}\text { Wave 3 } \\
(\mathbf{2 0 1 2})\end{array}$ & $\begin{array}{l}\text { Wave 4 } \\
(\mathbf{2 0 1 4 / 1 5 )}\end{array}$ & $\begin{array}{l}\text { Wave 5 } \\
(\mathbf{2 0 1 7})\end{array}$ \\
\hline Aged 0-2 & 1614 & 226 & 0 \\
& $(19.47)$ & $(2.73)$ & $(0.00)$ \\
\hline Aged 3-5 & 1877 & 1688 & 618 \\
& $(22.64)$ & $(20.36)$ & $(7.45)$ \\
\hline Aged 6-15 & 4800 & 5973 & 5939 \\
& $(57.89)$ & $(72.04)$ & $(71.63)$ \\
\hline Aged 16-18 & 0 & 404 & 1734 \\
& $(0.00)$ & $(4.87)$ & $(20.91)$ \\
\hline Total & 8291 & 8291 & $(100)$ \\
\hline
\end{tabular}

Source: NIDS 2012, 2014/2015, and 2017

Notes: Sample of children aged 18 years and younger in 2017. Only balanced sample included.

Table 4: Uncensored Headcount Ratios (percentage of sample identified as residing in household which is identified as being poor in specific dimension)

\begin{tabular}{|c|c|c|c|c|c|c|}
\hline \multirow[t]{2}{*}{ Dimension } & \multirow[t]{2}{*}{ Indicator } & \multirow[t]{2}{*}{$\begin{array}{l}\text { Weight } \\
\text { (indicator) }\end{array}$} & \multirow[t]{2}{*}{$\begin{array}{l}\text { Weight } \\
\text { (dimension) }\end{array}$} & \multicolumn{3}{|c|}{$\begin{array}{l}\text { Uncensored headcount } \\
\text { ratios }\end{array}$} \\
\hline & & & & 2012 & $2014 / 15$ & 2017 \\
\hline Health & Child mortality & & $1 / 4$ & $0.57 \%$ & $0.50 \%$ & $0.20 \%$ \\
\hline \multirow[b]{2}{*}{ Education } & Years of schooling & $1 / 8$ & & $2.46 \%$ & $2.36 \%$ & $1.76 \%$ \\
\hline & $\begin{array}{l}\text { School } \\
\text { attendance }\end{array}$ & $1 / 8$ & $1 / 4$ & $0.71 \%$ & $0.70 \%$ & $0.58 \%$ \\
\hline \multirow{7}{*}{$\begin{array}{l}\text { Living } \\
\text { conditions }\end{array}$} & Fuel for lighting & $1 / 28$ & & $12.84 \%$ & $10.61 \%$ & $6.84 \%$ \\
\hline & Fuel for heating & $1 / 28$ & & $34.61 \%$ & $32.64 \%$ & $33.82 \%$ \\
\hline & Fuel for cooking & $1 / 28$ & & $22.37 \%$ & $20.84 \%$ & $16.31 \%$ \\
\hline & Water access & $1 / 28$ & $1 / 4$ & $29.81 \%$ & $28.17 \%$ & $28.77 \%$ \\
\hline & Sanitation type & $1 / 28$ & & $51.98 \%$ & $51.09 \%$ & $51.27 \%$ \\
\hline & Dwelling type & $1 / 28$ & & $22.12 \%$ & $20.53 \%$ & $21.00 \%$ \\
\hline & Asset ownership & $1 / 28$ & & $6.42 \%$ & $5.95 \%$ & $5.50 \%$ \\
\hline $\begin{array}{l}\text { Economic } \\
\text { activity }\end{array}$ & Unemployment & & $1 / 4$ & $36.31 \%$ & $30.22 \%$ & $31.77 \%$ \\
\hline
\end{tabular}

Source: NIDS 2012, 2014/2015, and 2017.

Notes: Poverty rates were calculated for the sample of children aged 18 or younger in 2017 and who remained in the sample throughout the three waves (data have been weighted using panel weights). 
Table 5: Percentage of MPI poor and MPI non-poor children deprived in each indicator

\begin{tabular}{|l|lll|lll|}
\hline & \multicolumn{3}{l}{ MPI poor } & & \multicolumn{3}{l|}{ MPI non-poor } \\
& $\mathbf{2 0 1 2}$ & $\mathbf{2 0 1 4 / 1 5}$ & $\mathbf{2 0 1 7}$ & $\mathbf{2 0 1 2}$ & $\mathbf{2 0 1 4 / 1 5}$ & $\mathbf{2 0 1 7}$ \\
\hline Child mortality & $2.54 \%$ & $1.39 \%$ & $0.40 \%$ & $0.18 \%$ & $0.35 \%$ & $0.16 \%$ \\
Years of schooling & $10.00 \%$ & $9.72 \%$ & $10.37 \%$ & $0.96 \%$ & $1.15 \%$ & $0.47 \%$ \\
School attendance & $1.67 \%$ & $1.39 \%$ & $1.95 \%$ & $0.52 \%$ & $0.59 \%$ & $0.37 \%$ \\
Fuel for lighting & $39.45 \%$ & $34.89 \%$ & $22.57 \%$ & $7.55 \%$ & $6.64 \%$ & $4.49 \%$ \\
Fuel for heating & $84.82 \%$ & $82.44 \%$ & $79.43 \%$ & $24.63 \%$ & $24.49 \%$ & $26.99 \%$ \\
Fuel for cooking & $69.91 \%$ & $64.12 \%$ & $52.19 \%$ & $12.92 \%$ & $13.76 \%$ & $10.93 \%$ \\
Water access & $76.55 \%$ & $75.53 \%$ & $79.73 \%$ & $20.53 \%$ & $20.42 \%$ & $21.13 \%$ \\
Sanitation type & $96.38 \%$ & $95.89 \%$ & $95.83 \%$ & $43.16 \%$ & $43.75 \%$ & $44.59 \%$ \\
Dwelling type & $42.48 \%$ & $50.97 \%$ & $42.29 \%$ & $18.07 \%$ & $15.55 \%$ & $17.81 \%$ \\
Asset ownership & $20.93 \%$ & $20.87 \%$ & $20.54 \%$ & $3.54 \%$ & $3.52 \%$ & $3.25 \%$ \\
Unemployment & $98.94 \%$ & $98.22 \%$ & $99.20 \%$ & $23.87 \%$ & $19.09 \%$ & $21.66 \%$ \\
\hline
\end{tabular}

Source: NIDS 2012, 2014/2015, and 2017.

Notes: Poverty rates were calculated for the sample of children aged 18 or younger in 2017 and who remained in the sample throughout the three waves (data have been weighted using panel weights). Table indicates the proportion of children classified as being MPI poor using the poverty cut-off of $33.33 \%$. 